\title{
Inhalant substance abuse among adolescents in Manipur, India: An upcoming issue
}

\section{Rajkumari Bishwalata, Indira Raleng}

Department of Community

Medicine, Jawaharlal Nehru Institute of Medical Sciences, Imphal, Manipur, India

Address for the Correspondence: Dr. Rajkumari Bishwalata,

Department of Community

Medicine, Jawaharlal Nehru Institute of Medical Sciences, Imphal, Manipur - 795 010, India

E-mail:dr.bishwalata@ rediffmail.com

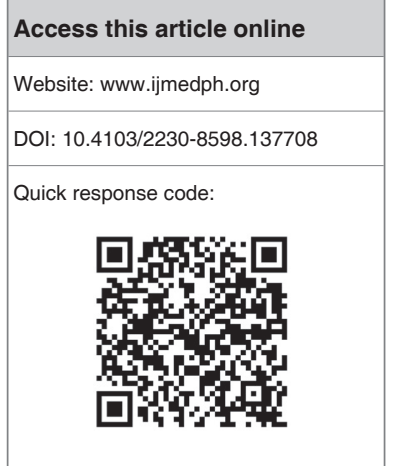

Background: Inhalant use, an important, yet-under recognized form of substance abuse has been reported commonly among adolescents in India but the true extent of the problem is not known due to paucity of data. Aims: To assess the prevalence and determinants of inhalant substance used amongst the adolescents in Manipur. Settings and Design: This cross sectional study was conducted among 1671 adolescent studying in Eighth to Twelfth standard in schools of Imphal-East District Manipur, India during March to June 2013. Materials and Methods: Schools were selected by simple random method and a semi-structured self-administered questionnaire adapted from the 'UNDCP/WHO Global initiative on Primary Prevention of substance abuse' was used for data collection. Univariate and Multiple logistic regression analysis were performed for association between ever users and selected variables. Results: Mean (SD) age of the students was 14.5(1.32) years, with males constituting 923(55.2\%). Prevalence of ever users was186 (11.1\%) and glue/ dendrite was the commonest substance abused $98(52.7 \%)$. Being male, belonging to joint family and increase in age were found to have significant higher risk of being a user, whereas higher level of parental education shows a protective effect. Conclusion: An increased effort for prevention, treatment along with sensitization of parents and teachers is a distinct challenge for policy makers.

Key words: Adolescents, glue/ dendrite, inhalant use, Manipur

\section{INTRODUCTION}

The term inhalants include a wide range of pharmacologically diverse substances that readily vaporize. Inhalant abusers use these volatile products that are capable of producing a quick and generally pleasurable sensory experience, that quickly dissipates leaving little or minimal "hangover" symptoms. These substances are widely available, inexpensive, easily concealed and legal for specific intended uses but are intentionally misused by abusers ${ }^{[1]}$ The effects include slurred speech, light headedness, euphoria, hallucinations, drowsiness etc. Long term consequences including liver, kidney damage and hearing loss has been reported. ${ }^{[2]}$ Inhalants are appealing to adolescents since the "high" achieved with inhalants occurs rapidly and disappears relatively quickly, compared with other drugs. Thus, a user can sniff after school and still return home sober. ${ }^{[3]}$

There are few reports on inhalant use in India which are mostly clinic based or case reports. ${ }^{[4-7]}$ Few studies have reported inhalant abuse among street children and it has also been linked to school dropout. ${ }^{[3,8]}$ Inhalant use among children has been seen to precede or act as a predictor for substance use later as they grow up. ${ }^{[9-12]}$

Despite long standing awareness of the significant morbidity and mortality associated with inhalant abuse, research and concrete data on its use and effects has been comparatively sparse in India. For these reasons, we took up this study to have a preliminary idea about the prevalence and associated factors of inhalant use among adolescents in our State.

\section{MATERIALS AND METHODS}

This cross sectional study was conducted in high schools and higher Secondary schools located in Imphal East District of Manipur, a state in the North-Eastern part of India during March to 
June 2013. Study population comprises of all adolescent school children studying in standard Eighth to Twelfth in the sampled schools. Sample size was calculated based on a prevalence of $9.9 \%$ among $10^{\text {th }}$ grade school children ${ }^{[13]}$ by using a precision of $1.5 \%$ and at 5\% significance level a sample size of 1522 was calculated. Assuming a little more than $10 \%$ non-responders, the sample size was increased to 1600 .

\section{Sampling design}

From the list of high schools and higher secondary schools located in the district the schools were sampled sequentially using lottery method and all eligible students in the selected schools were included. Absentees on the date of visit and refusals to participate were excluded. A total of 12 schools were selected till the required sample size was reached.

Study tool comprises of a self-administered, semi-structured questionnaire which was adapted from the 'UNDCP/WHO Global initiative on Primary Prevention of substance abuse- Overall Evaluation: Baseline Assessment Guidelines and instruments'. ${ }^{\text {, }}{ }^{14]}$ The questionnaire contained two parts- the Socio-demographic profile like age, sex, class, religion, father's and mother's educational qualifications and occupations, family type etc. and the KAP questions: based on knowledge, attitude and practice on inhalant substance abuse.

\section{Collection procedure}

After giving brief introduction and purpose of our visit, verbal informed consent was obtained from the participants. Students were requested to give the correct and true information without concealing anything as the information obtained will be used for research purpose only maintaining strict confidentiality. Any unclear question(s) were clarified and participants were informed that any question which they feel uncomfortable to answer may be omitted.

After collecting the questionnaire a short interactive health talk was delivered for about 30 to $40 \mathrm{~min}$ with the school teachers in attendance. Basic knowledge like risk factors for abusing inhalants, their side effects and methods to prevent inhalant substance abuse were provided to the students.

\section{Operational definitions}

Inhalants were defined as volatile substances that release chemical vapours that can be inhaled to induce a psychoactive or mind altering effect. Inhalant abuser - Any adolescent who ever abuse inhalant (s) for its psychoactive effects.

\section{Statistical analysis}

Data collected was entered into Ms Excel spreadsheet and transferred to SPSS version 11.5. Descriptive statistics like mean, median, percentages and analytical statistics like chi-square test and multiple logistic regression analysis were performed to look for association between ever users and selected variables. A $P<0.05$ was taken to be significant.

\section{Ethical issues}

Permission from school authorities was obtained prior to visiting the schools. Purpose of study was explained and Verbal informed consent was taken from the participants and strict confidentiality was maintained. An interactive health talk was given after data collection.

\section{RESULTS}

A total of 12 schools were selected, consisting of 4 Govt. schools and 8 private schools. The number of eligible students was 1993 , out of which 332 were absent on the day of visit, so 1671 students were included in the study. There were no refusals to participate.

Males constitute $923(55.2 \%)$ and majority of the study population $519(30.9 \%)$ were of 14 years with maximum proportion $521(30.25 \%)$ of students belonging to $9^{\text {th }}$ Grade. As the $10^{\text {th }}$ board results were still awaited during the study period there were no eleventh class students enrolled in any of the schools. Almost half $910(54.5 \%)$ of the students belong to hindu religion and majority of them $1009(60.4 \%)$ belong to nuclear family [Table 1].

Most of the students 1207 (72\%) have heard about inhalant substances and $345(20.6 \%)$ of them feels that it will be very easy to obtain such substances if they wanted. Around 682 (40.8\%) reported knowing classmates who are users. Majority 620 (37.10\%) responded 'peer pressure' being the reason for abuse and almost half of the respondents $691(41.4 \%)$ were not aware about harmful effects of inhalant use. In many of the families $578(34.6 \%)$ the issues of drugs and drug abuse were never discussed [Table 2].

The study recorded a prevalence of $186(11.1 \%)$ of ever users with first time use being highest during 13 to 14 years of age $73(39.2 \%)$. Majority of them $150(80.6 \%)$ reported 'friends' as the one who introduced them to inhalant use and 'glue/dendrite' 98 (52.7\%) was the substance most commonly abused followed by 'Correction fluid/ Eraz-X' 57 (30.6\%). A few of the ever users 11 (5.9\%) reported use of other oral drugs like 'SP/N10'(Spasmo-proxyvon/ Nitrazepam) besides using inhalants. Majority of them $152(81.7 \%)$ have tried to quit the habit in the past and $68(36.6 \%)$ reported being absent from school or having poor school performance due to the habit [Table 3].

Table 4 shows the crude and adjusted logistic regression analysis with being 'ever users' or not as the dependent variable with selected independent variables. Males showed a significantly higher risk of being a user as compared to females (OR 4.037, 95\% CI 2.655 to 6.139). The odds of being a user significantly increase with increasing age (OR 2.355, 95\% CI 1.587 to 3.494). The crude analysis showed an increasing risk of exposure with increasing grades from $8^{\text {th }}$ to $12^{\text {th }}$ grade but this effect was no longer seen in the adjusted analysis. Higher the father's education, the risk of being a user decreases significantly but no such relationship is observed with mother's educational level. Ever users are significantly more likely to come from joint families (OR 1.633, 95\% CI 1.165 to 2.289 ) as compared to nuclear family and being an user is significantly more likely to know classmates who were also users (OR 3.017, 955 CI 2.106-4.321). 


\begin{tabular}{|c|c|c|c|}
\hline Characteristics & $N(\%)$ & $\begin{array}{c}\text { Ever Users, } \\
N(\%) \\
\end{array}$ & $\begin{array}{c}\text { Non-Users, } \\
N(\%) \\
\end{array}$ \\
\hline \multicolumn{4}{|l|}{ Age (year) } \\
\hline 12 & $40(2.4)$ & $0(0)$ & $40(100)$ \\
\hline 13 & $391(23.4)$ & $19(4.9)$ & $372(95.1)$ \\
\hline 14 & $516(30.9)$ & $50(9.7)$ & $466(90.3)$ \\
\hline 15 & $409(24.5)$ & $53(13.0)$ & $356(87.0)$ \\
\hline 16 & $154(9.2)$ & $30(19.5)$ & $124(80.5)$ \\
\hline 17 & $122(7.3)$ & $25(20.5)$ & $97(79.5)$ \\
\hline 18 & $39(2.3)$ & $9(23.1)$ & $30(76.9)$ \\
\hline \multicolumn{4}{|l|}{ Gender } \\
\hline Male & $923(55.2)$ & $156(16.9)$ & $767(83.1)$ \\
\hline Female & $748(44.8)$ & $30(4.0)$ & $718(96.0)$ \\
\hline \multicolumn{4}{|l|}{ Class } \\
\hline $8^{\text {th }}$ & $490(29.3)$ & $30(6.1)$ & $460(93.9)$ \\
\hline $9^{\text {th }}$ & $521(31.2)$ & $52(10.0)$ & $469(90.0)$ \\
\hline $10^{\text {th }}$ & $457(27.3)$ & $68(14.9)$ & $389(85.1)$ \\
\hline $12^{\text {th }}$ & $203(12.1)$ & $36(17.7)$ & $167(82.3)$ \\
\hline \multicolumn{4}{|l|}{ School type } \\
\hline Government school & $287(17.2)$ & $40(13.9)$ & $247(86.1)$ \\
\hline Private school & $1384(82.8)$ & $146(10.5)$ & $1238(89.5)$ \\
\hline \multicolumn{4}{|l|}{ Religion } \\
\hline Hindu & $910(54.5)$ & $76(8.4)$ & $834(91.6)$ \\
\hline Islam & $241(14.4)$ & $26(10.8)$ & $215(89.2)$ \\
\hline Christian & $289(17.3)$ & $62(21.5)$ & $227(78.5)$ \\
\hline Others & $231(13.8)$ & $22(9.5)$ & $209(90.5)$ \\
\hline \multicolumn{4}{|l|}{ Father's education } \\
\hline Illiterate & $37(2.2)$ & $13(35.1)$ & $24(64.9)$ \\
\hline Upto $10^{\text {th }}$ & $552(33.0)$ & $66(12.0)$ & $486(88.0)$ \\
\hline Upto $12^{\text {th }}$ & $410(24.5)$ & $42(10.2)$ & $368(89.9)$ \\
\hline Graduate and above & $672(40.2)$ & $65(9.7)$ & $607(90.3)$ \\
\hline \multicolumn{4}{|l|}{ Mother's education } \\
\hline Illiterate & $142(8.5)$ & $25(17.6)$ & $117(82.4)$ \\
\hline Upto $10^{\text {th }}$ & $742(44.4)$ & $86(11.6)$ & $656(88.4)$ \\
\hline Upto $12^{\text {th }}$ & $343(20.5)$ & $38(11.1)$ & 305 (88.9) \\
\hline Graduate and above & $444(26.6)$ & $37(8.3)$ & $407(91.7)$ \\
\hline \multicolumn{4}{|l|}{ Type of family } \\
\hline Nuclear & $1009(60.4)$ & $95(9.4)$ & $914(90.6)$ \\
\hline Joint & $662(39.6)$ & $91(13.7)$ & $571(86.3)$ \\
\hline Total & $1671(100)$ & $186(11.1)$ & $1485(88.9)$ \\
\hline
\end{tabular}

\section{DISCUSSION}

Though, the overall prevalence of ever user of inhalants in this study was $11.1 \%$ this could be an underestimate of the real problem as absentees, school dropouts were not covered and some of the students might not be giving the true response. But the study, do confirms the general belief of the people of the region that inhalant use among school children is prevalent. However, further studies are necessary to understand the epidemiology and diverse extent of this problem.

In the study, males are significantly more likely to be ever users of inhalants as compared to females. These may relate to their

\begin{tabular}{|c|c|}
\hline Variable & $\begin{array}{l}\text { Response, } \\
\quad N(\%)\end{array}$ \\
\hline \multicolumn{2}{|c|}{ Aware of any substance use as inhalant } \\
\hline Yes & $1232(73.7)$ \\
\hline No & $439(26.3)$ \\
\hline \multicolumn{2}{|c|}{$\begin{array}{l}\text { Difficulty in obtaining such substance if you want } \\
\text { some? }\end{array}$} \\
\hline Probably impossible & $440(26.3)$ \\
\hline Very difficult & $391(23.40$ \\
\hline Fairly difficult & $246(14.7)$ \\
\hline Fairly easy & $249(14.9)$ \\
\hline Very easy & $345(20.6)$ \\
\hline \multicolumn{2}{|c|}{ Know any user classmate } \\
\hline Yes & $682(40.8)$ \\
\hline No & $989(59.2)$ \\
\hline \multicolumn{2}{|c|}{ How many users you know of? } \\
\hline $1-3$ & $418(25.0)$ \\
\hline $4-6$ & $133(8.0)$ \\
\hline$\geq 7$ & $131(7.8)$ \\
\hline Total & $682(40.8)$ \\
\hline \multicolumn{2}{|c|}{$\begin{array}{l}\text { Why do they abuse such substances (multiple } \\
\text { answer) }\end{array}$} \\
\hline Curiosity & $475(28.4)$ \\
\hline Peer pressure & $620(37.10)$ \\
\hline Frustrations & $311(18.61)$ \\
\hline Fashionable & $157(9.39)$ \\
\hline \multicolumn{2}{|c|}{$\begin{array}{l}\text { How often the issues of drugs and drug addiction } \\
\text { discuss in your family? }\end{array}$} \\
\hline Never discussed & $578(34.6)$ \\
\hline Sometimes & $896(53.6)$ \\
\hline Very often & $127(7.6)$ \\
\hline Almost daily & $70(4.2)$ \\
\hline \multicolumn{2}{|c|}{$\begin{array}{l}\text { Aware of any harmful health effects of inhalant } \\
\text { use? }\end{array}$} \\
\hline yes & $980(58.6)$ \\
\hline No & $691(41.4)$ \\
\hline \multicolumn{2}{|c|}{$\begin{array}{l}\text { Any seminar/lecture on substance abuse } \\
\text { conducted in the school }\end{array}$} \\
\hline Yes & $1066(63.8)$ \\
\hline No & $605(36.2)$ \\
\hline \multicolumn{2}{|c|}{$\begin{array}{l}\text { Approve or disapprove of young people using } \\
\text { inhalants }\end{array}$} \\
\hline approve & $94(5.6)$ \\
\hline disapprove & $1154(69.0)$ \\
\hline Can’t say & $423(25.3)$ \\
\hline \multicolumn{2}{|c|}{$\begin{array}{l}\text { How much young people risk in harming } \\
\text { themselves if inhalants used regularly }\end{array}$} \\
\hline No risk & 49 (2.9) \\
\hline Slight risk & $44(2.6)$ \\
\hline Moderate risk & $65(3.9)$ \\
\hline Great risk & $964(57.7)$ \\
\hline Don't know & $549(32.9)$ \\
\hline
\end{tabular}

aggressive nature and risk taking behaviour. Moreover as adolescents are in a transitional phase, confusion can make them susceptible to take up the unfavourable habit as an act of rebellion against parents and elders. Initiation of inhalant use started at around 13 to 14 years 


\begin{tabular}{|c|c|c|c|}
\hline Variable & Response, $N(\%)$ & Variable & Response, $N(\%)$ \\
\hline Have you ever used inhalants & & Lighter fluid & $10(5.4)$ \\
\hline Yes & $186(11.1)$ & Spray paint & $7(3.8)$ \\
\hline No & $1485(88.9)$ & Shoe polish & $7(3.8)$ \\
\hline Total & $1671(100)$ & Gasoline & $5(2.7)$ \\
\hline When do you use for first time & & Paint thinner & $2(1.1)$ \\
\hline$\leq 10$ year & $23(12.4)$ & Parents know about your addiction & \\
\hline $11-12$ year & $45(24.2)$ & Yes & $16(8.6)$ \\
\hline 13-14 year & $73(39.2)$ & No & $170(91.4)$ \\
\hline $15-16$ year & $33(17.7)$ & Use any other oral substance/drugs(SP/N10 etc) & \\
\hline$\geq 17$ year & $12(6.5)$ & Yes & $11(5.9)$ \\
\hline Total & $186(100)$ & No & $175(94.1)$ \\
\hline Did you use in last 1 month & & Ever taken to doctor for detox/de-addiction & \\
\hline Yes & $61(32.8)$ & Yes & $8(4.3)$ \\
\hline No & $125(67.2)$ & No & $178(95.7)$ \\
\hline How often do you use & & From where do you manage money to buy & \\
\hline Daily & $11(5.9)$ & From parents & $94(50.5)$ \\
\hline 3-4 times a week & $14(7.5)$ & From relatives & $27(14.5)$ \\
\hline 1-2 days a week & $27(14.5)$ & From friends & $51(27.4)$ \\
\hline 2-3 days a month & $28(15.1)$ & Part time jobs & $14(7.5)$ \\
\hline Once/ twice in past 12 months & $54(29.0)$ & From where you procure/get these substances & \\
\hline Didn't use any in past 12 months & $52(28.0)$ & Shops & $103(55.4)$ \\
\hline Where do you learn these habits & & From friends & $47(25.3)$ \\
\hline At home/relative house & $15(8.1)$ & Dealers & $8(4.3)$ \\
\hline Friend's place & $80(43.0)$ & relatives & $3(1.6)$ \\
\hline At school/college & $46(24.7)$ & Available at home & $25(13.5)$ \\
\hline Public places & $23(12.4)$ & Any of your family member use & \\
\hline Hostel/boarding school/ Rented place & $22(11.8)$ & Yes & $37(19.9)$ \\
\hline Who introduced you to inhalants & & No & $149(80.1)$ \\
\hline Friends & $150(80.6)$ & Tried to stop/quit & \\
\hline Family/relative & $8(4.3)$ & Yes & $152(81.7)$ \\
\hline Casual acquaintance & $4(2.2)$ & No & $34(18.3)$ \\
\hline Shopkeeper/druggist & $4(2.2)$ & Most common place for inhaling & \\
\hline dealer & $3(1.6)$ & Friend's place & $52(28.0)$ \\
\hline Self/no one & $17(9.1)$ & School toilet/playground & $21(11.3)$ \\
\hline Do you use alone or with someone & & Open fields & $62(33.3)$ \\
\hline With friends & $147(79.0)$ & Home/bedroom & $17(9.1)$ \\
\hline Alone & $20(10.8)$ & Classroom & $5(2.7)$ \\
\hline With classmates & $17(9.1)$ & Boarding school/hostel room & $29(15.6)$ \\
\hline With Family/relative & $2(1.1)$ & Absent from school or poor performance due & \\
\hline Substance used commonly & & to inhalant use & \\
\hline Glue/dendrite & $98(52.7)$ & Yes & $68(36.6)$ \\
\hline Correction fluid/Eraz-X & $57(30.6)$ & No & $118(63.4)$ \\
\hline
\end{tabular}

for $39.2 \%$ of the ever users. In western society also inhalant use tends to start early, with $58 \%$ of users reporting first use by the end of ninth grade. ${ }^{[15]}$

An increasing trend in the use of inhalants with increasing age is seen in this study which is contrary to findings of studies in western countries. ${ }^{[16]}$ Present conflict situation in this part of the country, low socio-economic status, poor parental education and awareness about the problem with the added increasing risk taking behaviour of adolescents with increasing age, peer pressures, frustration and emotional problems may be the reason for this difference. However; father's education seems to have a protective role against inhalant abuse thus emphasising the importance of parental education and awareness for prevention and control of the problem. Low level of parental education has been shown to be important risk factor for inhalant use among middle and high school students. ${ }^{[15]}$ The study also shows an increasing trend in prevalence with increasing class with the lowest prevalence among eighth standard (6.1\%) and highest among twelfth standard $(17.1 \%$.) which is contrast to the trend in prevalence in some studies conducted in western countries which shows decreasing trend with higher grades. ${ }^{[17]}$ Among the adolescents, those who belong to Christianity are significantly more likely to be users. This may be due to their more lenient life styles, availability of more pocket 


\begin{tabular}{|c|c|c|c|c|c|c|}
\hline Characteristic & Crude OR & $95 \% \mathrm{Cl}$ & $P$ value & Adjusted OR & $95 \% \mathrm{Cl}$ & $P$ value \\
\hline \multicolumn{7}{|l|}{ Gender } \\
\hline Female & 1 & & & 1 & & \\
\hline Male & 4.756 & $3.174-7.125$ & 0.000 & 4.037 & $2.655-6.139$ & 0.000 \\
\hline \multicolumn{7}{|l|}{ Class } \\
\hline VIII & 1 & & & 1 & & \\
\hline IX & 1.664 & $1.041-2.659$ & 0.03 & 0.933 & $0.545-1.596$ & 0.80 \\
\hline$x$ & 2.680 & $1.709-4.205$ & 0.000 & 1.131 & $0.642-1.992$ & 0.67 \\
\hline XII & 3.085 & $1.831-5.197$ & 0.000 & 0.518 & $0.228-1.175$ & 0.116 \\
\hline Age (year) & 2.210 & $1.736-2.814$ & 0.000 & 2.355 & $1.587-3.494$ & 0.000 \\
\hline \multicolumn{7}{|l|}{ Family type } \\
\hline Nuclear & 1 & - & & 1 & & \\
\hline Joint & 1.554 & $1.142-2.115$ & 0.000 & 1.633 & $1.165-2.289$ & 0.004 \\
\hline \multicolumn{7}{|l|}{ Religion } \\
\hline Hindu & 1 & & & 1 & & \\
\hline Muslim & 1.366 & $0.853-2.189$ & 0.19 & 1.401 & $0.837-2.347$ & 0.20 \\
\hline Christian & 3.023 & $2.089-4.372$ & 0.000 & 2.326 & $1.534-3.526$ & 0.000 \\
\hline Others & 1.189 & $0.722-1.960$ & 0.49 & 1.094 & $0.638-1.874$ & 0.74 \\
\hline \multicolumn{7}{|c|}{ Father's educational level } \\
\hline Illiterate & 1 & & & 1 & & \\
\hline Upto $10^{\text {th }}$ & 0.251 & $0.122-0.516$ & 0.000 & 0.329 & $0.140-0.770$ & 0.010 \\
\hline Upto $12^{\text {th }}$ & 0.194 & $0.092-0.411$ & 0.000 & 0.219 & $0.090-0.533$ & 0.001 \\
\hline Graduate and above & 0.198 & $0.096-0.407$ & 0.000 & 0.284 & $0.118-0.681$ & 0.005 \\
\hline \multicolumn{7}{|c|}{ Mother's educational level } \\
\hline Illiterate & 1 & & & & & \\
\hline Upto $10^{\text {th }}$ & 0.589 & $0.392-0.961$ & 0.03 & 0.893 & $0.498-1.602$ & 0.70 \\
\hline Upto $12^{\text {th }}$ & 0.583 & $0.337-1.008$ & 0.05 & 0.900 & $0.464-1.748$ & 0.75 \\
\hline Graduate and above & 0.425 & $0.246-0.736$ & 0.002 & 0.832 & $0.419-1.651$ & 0.59 \\
\hline \multicolumn{7}{|c|}{ Know any user classmate } \\
\hline No & 1 & & & 1 & & \\
\hline Yes & 4.039 & $2.890-5.644$ & 0.000 & 3.017 & $2.106-4.321$ & 0.000 \\
\hline
\end{tabular}

money or the Christian students were giving honest response. Ever users are more likely to belong to joint families than nuclear. In joint families, the parents/elders may be less vigilant about their children than in a close knit nuclear family.

In this study, only 59\% are aware of any health related problems caused by using such substances. This may be due to lack of discussions among family members, lack of seminars or lectures in school regarding the inhalant substance abuse and its consequences. As our state is one of the high prevalent states in the HIV/AIDS scenario most of the health awareness campaigns cum seminars held in schools so far have been focussing on oral and intravenous drug use and its consequences and the area of inhalant substance abuse has been ignored. Around 5.9\% of the ever users reported use of other psychoactive substances along with inhalant. Associations between early-onset inhalant use and risk for later heroin and intravenous drug use, antisocial behavior, and polydrug abuse have also been identified. ${ }^{[18]}$ Reports suggest that childhood and adolescent inhalant use may be an early warning sign for membership in a subgroup of antisocial youths who are marked by high levels of polydrug use and psychosocial impairment, as well as earlier onset of behavioural problems and antisocial conduct than are typical of non-users of inhalants. ${ }^{[19-21]}$

Glue/dendrite (71.16\%) appears to be the most common inhalant substance abused followed by correction fluid, lighter fluid etc. Such items are reported as commonly abused by adolescents in other studies. ${ }^{[22]}$ Recently local students' organisations have been demanding the ban of sale of such items to children but no legal actions have been taken up so far. Influence of peer pressure $(34.13 \%)$ is rated highest for initiating the habit. Other reasons being curiosity, frustration and some feels it's fashionable to be a user. We also found that users around $68 \%$ felt the need to give up the habit. Motivation and support on the part of the family, teachers and close ones should help the users to come out of this habit. The school being an essential part in a students' life can promote effective and healthy life styles and conduct lectures or seminars and thematic lessons on inhalant substance abuse.

We covered around 12 High Schools and Higher Secondary Schools including both Govt. and private schools of Imphal East District. Characteristics of adolescents in the state are more or less similar so our sample could be representative of the adolescent population 
in the State. Interactive Health Talk was given after collection of data that could clear their doubts and misconceptions. The students were provided with basic information about the health effects and long-term consequences of inhalant abuse and its prevention. They were advised to spread our messages to those whom we fail to reach in our study. Absentees could not be covered whose characteristics might differ from rest and the prevalence might be higher among them. A further study, with house to house survey can be taken up to cover the absentees, school dropouts and street children to get a better understanding of the problem.

\section{CONCLUSION}

Inhalant abuse offers a distinct challenge to parents as well as the health care provider, who needs to become more aware of the extent of the problem, the substances commonly abused and its health consequences. State Government should take up initiative and incorporate the problem and the adverse health effects of inhalants use in the school curriculum as early as the primary level. There is also a need to advocate for the replacement of dangerous and psychoactive substances in common products with less harmful alternatives.

\section{REFERENCES}

1. Williams JF, Storck M, American Academy of Pediatrics Committee on Substance Abuse; American Academy of Pediatrics Committee on Native American Child Health. Inhalant abuse. Pediatrics 2007;119:1009-17. Available from: http://www.pediatrics.aappublications. org/content/119/5/1009.full.html [Last accessed on 2013 Feb 10].

2. Inhalants. Drug facts. NIDA National Institute on Drug abuse. U.S. Department of Health and Human Services. National Institute of Health. September 2012. Available from: http://www.drugabuse.gov/publications/ reserch-reports/inhalant-abuse [Last accessed on 2013 Feb 10].

3. Cohen S. Inhalant abuse: An overview of the problem. NIDA Res Monogr 1977;15:2-11

4. Pahwa M, Baweja A, Gupta V, Jiloha RC. Petrol-inhalation dependence: A case report. Indian J Psychiatry 1998;40:92-4.

5. Kumar S, Grover S, Kulhara P, Mattoo SK, Basu D, Biswas P, et al. Inhalant abuse: A clinic-based study. Indian J Psychiatry 2008;50:117-20.

6. Narayanaswamy JC, Viswanath B, Ravi M, Muralidharan K. Inhalant dependence: Data from a tertiary care center in South India. Indian J Psychol Med 2012;34:232-6.

7. Basu D, Aggarwal M, Das PP, Mattoo SK, Kulhara P, Verma VK. Changing pattern of substance abuse in patients attending a de-addiction centre in North India (1978-2008). Indian J Med Res 2012;135:830-6.

8. Benegal V, Sheshadri SP, Chand PK, Lakshmana G, Subodh BN. Inhalant Use among street children in Bangalore: Funded by World Health
Organisation (India), 2008-09. Available from: http://www.nimhans.kar. nic.in/cam/CAM/Drug_abuse_among_street_children.pdf [Last accessed on 2014 Mar 28].

9. Praveen D, Maulik PK, Raghavendra B, Khan M, Guggilla RK, Bhatia P. Determinants of inhalant (whitener) use among street children in a South Indian city. Subst Use Misuse 2012;47:1143-50.

10. Seth R, Kotwal A, Ganguly KK. Street and Working Children of Delhi, India, Misusing Toluene: An Ethnographic Exploration. Subst Use Misuse 2005;40:1659-79.

11. Nigam AK, Srivastava RP, Chavan BS, Saxena S. Abuse of boot polish by inhalation and ingestion: A case report. Indian J Psychiatry 1993;35:63-4.

12. Hazarika NC, Biswas D, Phukan RK, Hazarika, Mahanta DJ. Prevalence and pattern of substance Abuse at Bandardewa, a border area of Assam and Arunachal Pradesh. Indian J Psychiatry 2000;42:262-6.

13. University of Michigan, Institute for Social Research. Monitoring the Future Study. 2009-2012. Available from: http://www.drugabuse.gov/ related-topics/trends-statistics/monitoring-future/trends-in-prevalencevarious-drugs [Last accessed on $2013 \mathrm{Feb} 10]$.

14. 'UNDCP/WHO Global initiative on Primary Prevention of substance abuseOverall Evaluation: Baseline Assessment Guidelines and instruments'. Available from: http://www.apps.who.int/iris/bitstream/10665/67751/1/ WHO_MSD_MER_02.10.pdf [Last accessed on $2013 \mathrm{Feb} 10]$.

15. University of Michigan, Institute for Social Research. Monitoring the Future Study. 2008. Available from: http://www.monitoringthefuture.org/ [Last accessed on 2013 Mar 6].

16. Kozel N, Sloboda Z, Rosa M. Epidemiology of inhalant abuse: An International Perspective. National Institute on Drug Abuse Research Monograph Series 148, 1995. U.S. Department of Human Service. National Institute of Health. Available from: http://archives.drugabuse. gov/pdf/monographs/148.pdf [ Last accessed on 2013 Mar 6]

17. Kurtzman TL, Otsuka KN, Wahl RA. Inhalant Abuse by Adolescents. J Adolesc Health 2001;28:170-80.

18. Results from the 2005 National Survey on Drug Use and Health: National Findings. SAMHSA 2005. Available from: http://www.samhsa.gov/data/ nsduh/2k5nsduh/2k5results.pdf [Last accessed on 2013 Mar 6].

19. Howard MO, Jenson JM. Inhalant use among antisocial youth: Prevalence and correlates. Addict Behav 1999;24:59-74.

20. Freedenthal S, Vaughn MG, Jenson JM, Howard MO. Inhalant use and suicidality among incarcerated youth. Drug Alcohol Depend 2007;90:81-8.

21. McGarvey EL, Canterbury RJ, Waite D. Delinquency and family problems in incarcerated adolescents with and without a history of inhalant use. Addict Behav 1996;21:537-42.

22. SAMHSA, Office of Applied Studies Inhalant Use Across the Adolescent Years. 2008b. The NSDUH Report, March 13 Available from: http://www. samhsa.gov/data/2k8/inhalants/inhalants.pdf [Last accessed on 2013 Mar 6].

How to cite this article: Bishwalata R, Raleng I. Inhalant substance abuse among adolescents in Manipur, India: An upcoming issue. Int J Med Public Health 2014;4:237-42.

Source of Support: Nil, Conflict of Interest: None declared. 